\title{
The end of the Last Glacial Maximum in the Iberian Peninsula characterized by the small-mammal assemblages
}

\author{
S. Bañuls-Cardona ${ }^{1,2}$, , J.M. López-García ${ }^{3}$, H.-A. Blain ${ }^{1,2}$, I. Lozano-Fernández ${ }^{1,2}$, \\ G. Cuenca-Bescós ${ }^{4}$

\begin{abstract}
${ }^{1}$ IPHES, Institut Català de Paleoecologia Humana i Evolució Social, C/Escorxador s/n, E- 43003 Tarragona, Spain
${ }^{2}$ Àrea de Prehistòria, Universitat Rovira i Virgili (URV), Avinguda de Catalunya 35, E-43002 Tarragona, Spain.

${ }^{3}$ Gruppo di Ricerca di Paleobiologia e Preistoria, Università di Ferrara, Ercole I d'Este 32, I-44121 Ferrara, Italy
\end{abstract} \\ ${ }^{4}$ Área de Paleontología, Dpto. Ciencias de la Tierra, Facultad de Ciencias, Universidad de Zaragoza. C/ Pedro Cerbuna 12, \\ E-50009 Zaragoza, Spain \\ e-mail addresses: sanbacard@gmail.com (S.B.-C., *corresponding author); jmlopez@iphes.cat (J.M.L.): hablain@iphes.cat (H.-A.B.); ilozano@iphes.cat (I.L.-F.); \\ cuencag@unizar.es (G.C.-B.)
}

Received: 12 May 2013 / Accepted: 6 December 2013 / Available online: 25 February 2014

\begin{abstract}
This paper presents a palaeoenvironmental and palaeoclimatic approach to the end of the Last Glacial Maximum (LGM) in the Iberian Peninsula on the basis of the small-mammal assemblages (insectivores, bats and rodents). The LGM is an important period in our climate history defined by the maximum extension of ice sheets between ca. 22 and $19 \mathrm{ka}$ BP. In the Mediterranean region the LGM is characterized by humid conditions, which allow for the development of arboreal vegetation. The small-mammal remains described in this study were recovered from four different sites within the Iberian Peninsula: El Mirón cave (Ramales de la Victoria, Cantabria), Valdavara-1 (Becerreá, Lugo), El Portalón (Sierra de Atapuerca, Burgos), and Sala de las Chimeneas (Maltravieso, Cáceres). We found in these sites a non-analogue association represented by species associated with mid-European climatic conditions, such as the voles Chionomys nivalis, Microtus arvalis, Microtus agrestis and Microtus oeconomus, together with species associated with Mediterranean requirements, such as Microtus (Iberomys) cabrerae and Microtus (Terricola) duodecimcostatus. These assemblages reveal that the climate was harsher than today in the sites under study, though not as rigorous as elsewhere in Europe, with mean annual temperatures lower than present and an environment dominated by wet open meadows. All our data have been compared with other environmental and climatic proxies, global isotope curves and pollen data, providing a scenario for the palaeoclimatic and palaeoenvironmental conditions that occurred during the LGM in the Iberian Peninsula.
\end{abstract}

Keywords: Microvertebrate, palaeoenvironment, palaeoclimate, LGM, Late Pleistocene

\section{Resumen}

Este artículo representa un enfoque paleoambiental y paleoclimático del final del Último Máximo Glacial (UMG), en la Península Ibérica a partir de las asociaciones de pequeños mamíferos (insectívoros, murciélagos y roedores). El UMG es un período importante en nuestra historia del clima definido por la máxima extensión de las capas de hielo entre ca. 22 y 19 ka BP. En la región del Mediterráneo, este UMG se caracteriza por condiciones de humedad, que permiten el desarrollo de la vegetación arbórea. Los restos de micromamíferos seleccionados para este estudio corresponden a cuatro yacimientos diferentes de la Península Ibérica: la cueva del Mirón (Ramales de la Victoria, Cantabria), Valdavara-1 (Becerreá, Lugo), El Portalón (Sierra de Atapuerca, Burgos), y la Sala de las Chimeneas (Maltravieso, Cáceres). En todos los yacimientos estudiados se ha encontrado una asociación representada por las especies relacionadas con las condiciones climáticas medio-europeas, como los topillos Chionomys nivalis, Microtus arvalis, Microtus agrestis o Microtus oeconomus, junto con las especies asociadas con los requerimientos mediterráneos, como Microtus (Iberomys) cabrerae o Microtus (terricola) duodecimcostatus. Estas asociaciones nos permiten observar que el clima era más frío que hoy en día en los diferentes yacimientos estudiados, pero no tan riguroso como en otros lugares de Europa, con temperaturas medias anuales más bajas que en la actualidad y un entorno dominado por prados húmedos. Los resultados de este estudio han sido comparados con otros datos ambientales y climáticos, las curvas climáticas globales de isótopos y datos polínicos, proporcionando un escenario para las condiciones paleoclimáticas y paleoambientales que ocurrieron durante el UMG en la Península Ibérica. 


\section{Introduction}

There are many papers that have studied the LGM in the Iberian Peninsula, but the importance of the present article lies in its new presentation of palaeoclimatic and palaeoenvironmental data based on the study of small mammals from this period, in other words, data acquired from terrestrial sequences, since up to now the published data have been obtained from marine cores collected off the coast of the Iberian Peninsula. The LGM (22-19 ka BP) is currently defined either as the period of maximum cold in the Northern Hemisphere, or as the period with the greatest extension of ice at the polar caps (Kageyama et al., 2005; Fletcher and Sánchez-Goñi, 2008). Some studies such as the Greenland ice-core record, have permitted the establishment of the complexity of the climatic variability of the last glacial cycle on the basis of its oxygen isotope curves (Sánchez-Goñi and D’Errico, 2005). Yet there have also been studies closer to the coasts of the Iberian Peninsula, such as marine core MD95-2042, located off the southwestern coast of Portugal, core MD99-2331 taken off the coast of Galicia, the core from Padul (Sierra Nevada) and core MD95-2043 from the Alboran Sea. These records have shown that during the LGM the Iberian Peninsula was characterized by conditions that were slightly more humid than in the rest of Europe (Kageyama et al., 2005; Peyron et al., 1998; Fletcher and Sánchez-Goñi, 2008). For the present characterization of the LGM, we have compared the data from the marine cores with palaeoenvironmental and palaeoclimatic data obtained from the study of small mammals from various sites in the Iberian Peninsula. Specifically, we have taken data from four sites located in different parts of the Iberian Peninsula that display contrasting climatological characteristics: the caves of Valdavara-1 (Becerreá, Lugo), El Mirón (Ramales de Victoria, Cantabria), El Portalón (Atapuerca, Burgos) and La Sala de las Chimeneas (Maltravieso, Cáceres) (Fig. 1).

\section{Study areas, materials and methods}

\subsection{Studied areas}

The faunal assemblages used here are included in the smallmammal studies of the following sites: Valdavara-1 (Becerreá, Lugo), from which we have used the data corresponding to level VLU (17890-17730 cal. BP) (Vaquero et al., 2009; López-García et al., 2011); El Mirón (Ramales de Victoria, Cantabria), from which we have taken the data belonging to levels 110 (20020-18660 cal. BP), 111 (20190-19070 cal. BP) and 16 (18750-17830 cal. BP) (Cuenca-Bescós et al., 2008; 2009); El Portalón (Atapuerca, Burgos), where we have used level P1 (20500-20140 cal. BP) (López-García et al., 2010a); and finally, La Sala de las Chimeneas (Maltravieso Cave, Cáceres), from which we have made use of the data from level 1 (19500-18700 cal. BP and 19700-18750 cal. BP) (Canals et al., 2010; Bañuls Cardona et al., 2012) (Fig. 1).

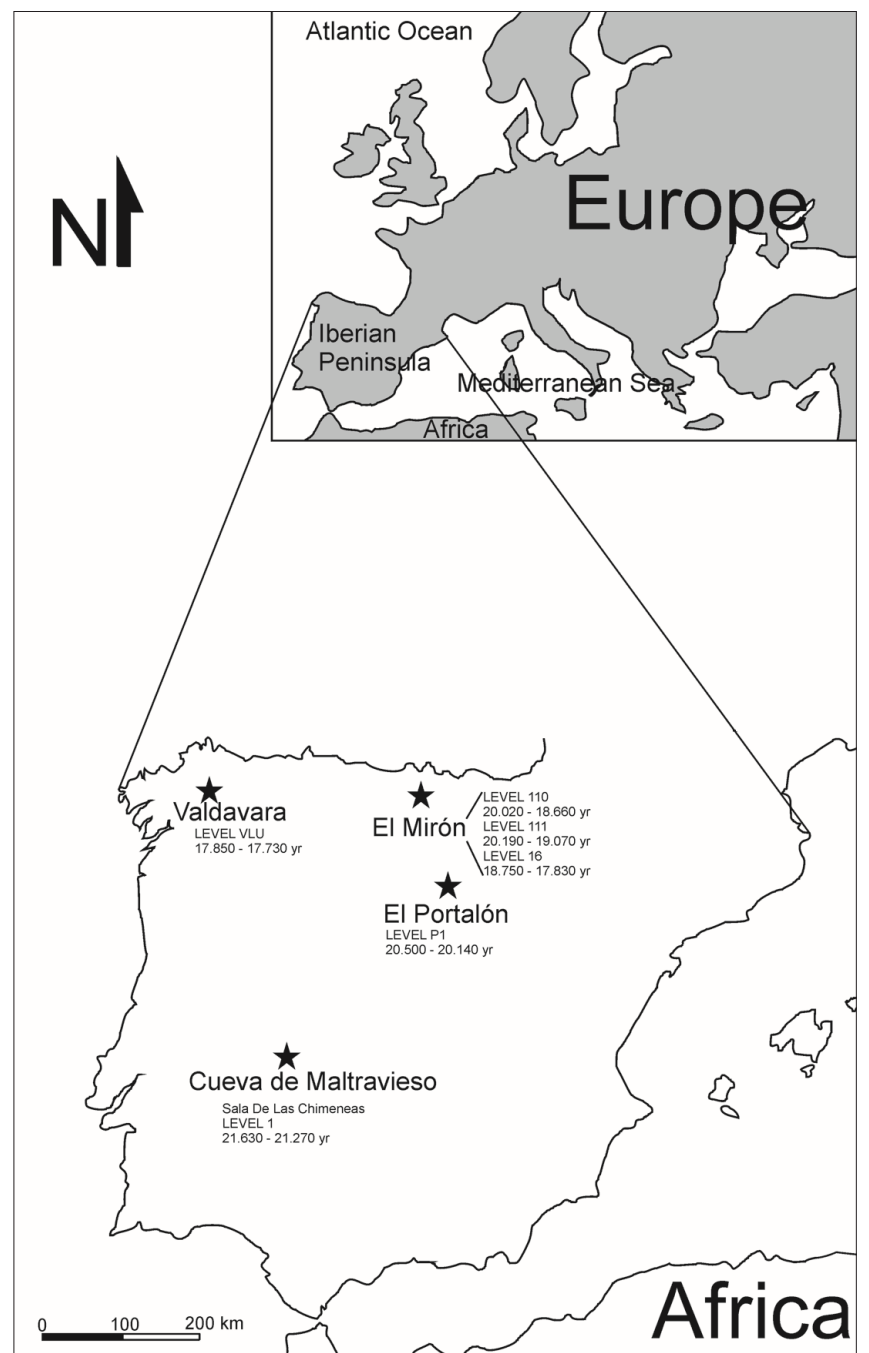

Fig. 1.- Geographic location of the sites under study, and the levels chosen from each of them with their corresponding radiocarbon dates. The abbreviations are as follows: VLD: Valdavara, MI: El Mirón, P: El Portalón, CH: Sala de las Chimeneas, OD: Open Dry, OH: Open Humid, WO: Woodland, RO: Rocky, WA: Water, CH1: species with Euro-Siberian requirements, $\mathrm{CH} 2$ : species tolerant with Mediterranian conditions, and $\mathrm{CH} 3$ : species with Mediterranean requirements.

\subsection{Small-mammal assemblage}

The faunal assemblages described in this paper are based on studies already published by López-García et al. (2010a; 2011), Cuenca-Bescós et al. (2009; 2010) and Bañuls Cardona et al. (2012). The small vertebrates were recovered using a water-screening system with meshes of decreasing size $(1 \mathrm{~cm}, 0.5 \mathrm{~cm}$ and $0.05 \mathrm{~cm})$. Each species was identified on the basis of cranial and post-cranial diagnostic elements from the skeleton of these small vertebrates, in accordance with systematic palaeontology (Reumer, 1984; Van der Meulen, 1973; Pasquier, 1974; Damms, 1981). Finally, the remains were grouped using the "minimum number of individuals" method (MNI), which was calculated with the most diagnostic anatomical parts. 
Most of the small-mammal remains are a product of the accumulation of pellets regurgitated by birds of prey, together with occasional contributions from small carnivores. These predators were identified after studying the fragmentation and/or digestion of the bones and teeth, establishing categories in this way (Andrews, 1990).

However, other remains are due to mortality during hibernation or aestivation in the cave, as in the case of bats (Sevilla, 1986), or to human commensalism (Pokines, 1998; Eastham, 1995). The published studies have established that at all the sites the predators were non-selective nocturnal birds of prey, since the digestion of the bones is slight or non-existent (Andrews, 1990); as for the chiropters, a natural death has been established in most cases (Sevilla, 1986).

Valdavara-1 (Becerreá, Lugo) contains a total of 129 individuals and 15 small-mammal taxa (López-García et al., 2011); El Mirón (Ramales de Victoria, Cantabria) contains a MNI of 276 and 12 small-mammal taxa (Cuenca-Bescós et al., 2008; 2009); El Portalón (Atapuerca, Burgos) has 83 individuals representing 8 small-mammal taxa (López- García et al., 2010a); and finally, at La Sala de las Chimeneas (Maltravieso Cave, Cáceres) a MNI of 150 has been calculated, and 12 small-mammal taxa have been identified (Bañuls Cardona et al., 2012) (Table 1).

\subsection{Palaeoenvironmental reconstruction}

The method of palaeoenvironmental reconstruction that has been used in this case was that of habitat weighting (Evans et al., 1981; Andrews, 2006; modified by Blain et al., 2008, López-García et al., 2011). This method involves ascertain- ing a percentage distribution for the habitat(s) preferentially occupied by each taxon. We took into account the geographical location of each species today, as all of them still exist in the Iberian Peninsula. We divided the habitats into five categories, defined according to a series of highly concrete environmental features: dry meadow, wet meadow, woodland, rocky areas and watercourse areas. "Dry meadow" consists of meadowland subject to seasonal climate change; "wet meadow" indicates evergreen meadowland with pastures and dense topsoil; "woodland" ranges from leafy forests to woodland margins, with moderate vegetation cover; "rocky areas" refer to rocky habitats without vegetation cover; and "areas around water" include streams, lakes and ponds (Table 1).

Furthermore, we have used a classification of taxa in accordance with the chorotypes established by Sans-Fuentes and Ventura (2000), Real et al. (2003) and López-García et al. (2010b). Chorotype 1 refers to species with Euro-Siberian requirements; this implies a mean summer temperature lower than $20^{\circ} \mathrm{C}$, a mean annual temperature that should be between $10^{\circ} \mathrm{C}$ and $12^{\circ} \mathrm{C}$, and a mean annual precipitation higher than $800 \mathrm{~mm}$. Chorotype 2 refers to Euro-Siberian species that nonetheless tolerate Mediterranean conditions, with a mean annual precipitation greater than $600 \mathrm{~mm}$. Chorotype 3 denotes species with strictly and not so strictly Mediterranean requirements (Table 1).

\subsection{Palaeoclimatic reconstruction}

In order to carry out the palaeoclimatic study the Mutual Climate Range method (MCR) was used (Blain, 2005; 2009; Blain et al., 2007; 2009; 2010; Agustí et al., 2009; López-

\begin{tabular}{|c|c|c|c|c|c|c|c|c|c|c|c|c|}
\hline \multirow{2}{*}{ TAXA } & \multicolumn{4}{|c|}{ NMI \% } & \multicolumn{5}{|c|}{ DISTRIBUTION BY HABITAT } & \multicolumn{3}{|c|}{ CHOROTYPES } \\
\hline & VLD & $\mathrm{MI}$ & $P$ & $\mathrm{CH}$ & OD & $\mathrm{OH}$ & WO & $\mathrm{RO}$ & WA & $\mathrm{CH}-1$ & $\mathrm{CH}-2$ & $\mathrm{CH}-3$ \\
\hline Arvicola sapidus & 11.5 & & & 4 & & & & & 1 & & & \\
\hline Arvicola terrestris & 6.3 & 34.8 & & 1.6 & & 1 & & & & & & \\
\hline Microtus arvalis & 9.4 & 8.7 & 24.7 & 4.8 & 0.5 & & 0.5 & & & $x$ & & \\
\hline Microtus agrestis & 5.2 & 2.5 & 28.6 & 3.2 & & 0.5 & 0.5 & & & $x$ & & \\
\hline Microtus arvalis-agrestis & & & 22.1 & & & & & & & & & \\
\hline Microtus oeconomus & & 6.5 & 3.9 & & & 0.5 & 0.5 & & & $x$ & & \\
\hline Chionomys nivalis & 20.8 & 7.2 & 14.3 & & & & & 1 & & $x$ & & \\
\hline Pliomys lenki & & 1.1 & & & & & & 1 & & & & \\
\hline Microtus (Iberomys) cabrerae & 2.1 & & 2.6 & 9.6 & & 0.5 & 0.5 & & & & & $\mathrm{x}$ \\
\hline $\begin{array}{l}\text { Microtus (Terricola) duodecimcostatus } \\
\text { Microtus (Terricola) lusitanicus }\end{array}$ & 177 & & & 6.4 & & 0.5 & 0.5 & & & & & $\mathrm{x}$ \\
\hline $\begin{array}{l}\text { Microtus (Terricola) lusitanicus } \\
\text { Apodemus sylvaticus }\end{array}$ & 17.7 & 5.8 & & & & 0.5 & 0.5 & & & & $\mathrm{x}$ & \\
\hline Apodemus sylvaticus & 10.4 & 1.4 & & 12 & & & 1 & & & & & $x$ \\
\hline Eliomys quercinus & 2.1 & & 1.3 & 3.2 & & 0.5 & 0.5 & & & & & $x$ \\
\hline $\begin{array}{l}\text { Glis glis } \\
\text { Crocidura russula }\end{array}$ & 4.2 & & & 16 & & & $\begin{array}{c}1 \\
05\end{array}$ & & & & & x \\
\hline Sorex araneus-coronatus & & & & 1.6 & 0.5 & & 0.5 & & & & $\mathrm{x}$ & $x$ \\
\hline Sorex minutus & 2.1 & & & & & 0.5 & 0.5 & & & & $x$ & \\
\hline Sorex sp. & 2.1 & & & & & 0.5 & 0.5 & & & $x$ & & \\
\hline Neomys fodiens & & 0.7 & & & & 0.2 & & & 0.8 & & $x$ & \\
\hline Neomys anomalus & & & 2.6 & & & 0.4 & 0.4 & & 0.2 & & $x$ & \\
\hline Talpa europaea & & 27.9 & & & & 0.5 & 0.5 & & & & $x$ & \\
\hline Talpa occidentalis & 4.2 & & & & & 0.5 & 0.5 & & & & & \\
\hline Erinaceus europaeus & 1 & & & 1.6 & & 0.5 & 0.5 & & & & & $x$ \\
\hline Myotis nathereri & 1 & & & & 0.25 & 0.25 & 0.5 & & & & & $x$ \\
\hline Myotis myotis blythii & & & & 5.6 & 0.25 & 0.25 & 0.5 & & & & & $\mathrm{x}$ \\
\hline Chiroptera indet. & & 0,4 & & & 0.25 & 0.25 & 0.5 & & & & & \\
\hline
\end{tabular}

Table 1.- MNI \% (percentage of MNI) and distribution of the taxa by habitat and chorotype. 

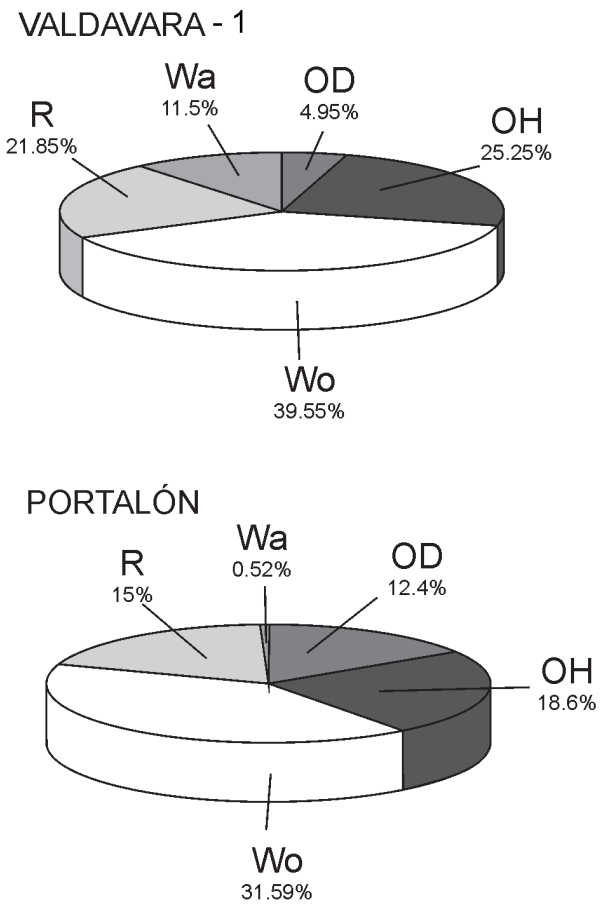

\section{SALA DE LAS CHIMENEAS}

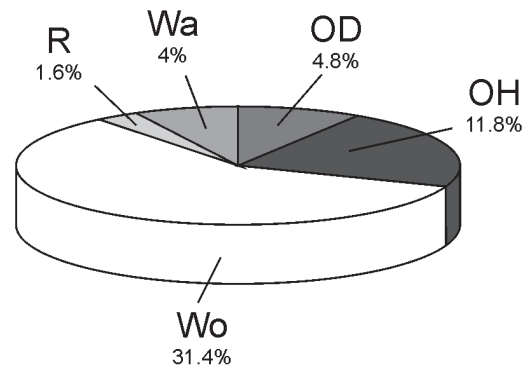

MIRÓN

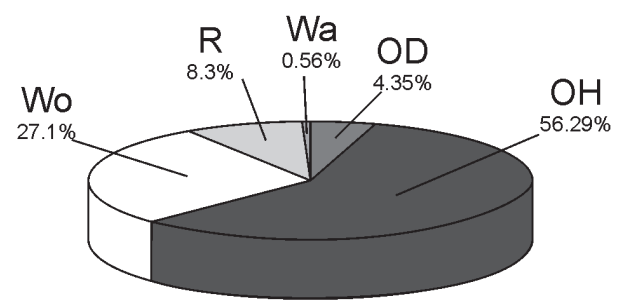

Fig. 2.- Percentage of the habitats represented at each site. The abbreviations are as follows: R: Rocky; WA: Water, OD: Open Dry, OH: Open Humid and WO: Woodland.
García et al., 2010a). From the studied aasemblages, certain taxa have been omitted from the present analysis: Microtus (Iberomys) cabrerae, Microtus oeconomus and the chiropters. Microtus (Iberomys) cabrerae has been discarded because its current distribution has been modified by anthropic activity, in particular by the cultivation and drainage of the wetland areas with which this taxon is associated (Palombo and Gisbert, 2005). Microtus oeconomus is a taxon that is not currently found in the Iberian Peninsula, so its actual distribution in the area is unknown, but in spite of this its climatic requirements have been taken into account in the general interpretation of the work. The omission of the chiropters is due to the fact that in many cases its mobility makes difficult to ascertain their present geographical distribution, which could thus falsify our data.

The method involves defining the current distribution area of the faunal association, superimposing current distribution maps divided into $10 \times 10 \mathrm{~km}$ UTM grids (Palombo and Gisbert, 2005). The resulting intersection indicates an area where the climatic characteristics are similar to those of our association. On the basis of this intersection we calculated the MAT (mean annual temperature), MTC (mean temperature of the coldest month) and the MTW (mean temperature of the warmest month), as well as the MAP (mean annual precipitation). These climatic characteristics are obtained using current maps of temperature and precipitation (Font Tullot, 2000). The quantitative data obtained were compared with the present-day climate of this region of the Iberian Peninsula, enabling us to note the changes in temperature and precipitation at this point of the Pleistocene.

\section{Results}

\subsection{Palaeoenvironmental reconstruction}

The analysis undertaken indicates a high humidity requirement at all the sites under study. Particularly noteworthy is the high percentage of species associated with woodland and wet open areas (Fig. 2). This is the case with El Mirón, which shows a very high percentage of taxa associated with wet open spaces (56.15\%), represented mainly by Talpa europaea (27.9\%) and Arvicola terrestris (34.8\%). However, species linked with watercourses are scarce; the most commonly represented among such species is Arvicola sapidus, which is mainly at the cave of Valdavara-1 (Fig. 2).

As for the scarce percentage representation of "dry environment" species, Valdavara-1 and El Portalón present the highest percentages, whereas La Sala de las Chimeneas presents the lowest. El Portalón is notable for its high percentage of "open dry" species (12.35\%), represented by Microtus arvalis $(12.35 \%)$, whereas in the case of Valdavara-1 its dry environment is represented by the $21.85 \%$ for "rocky" habitats, due above all to the presence of Chionomys nivalis (20.8\%). This species, which inhabits mainly rocky environments, also appears at El Portalón and El Mirón, though not at such high percentage levels (Fig. 2).

\subsection{Palaeoclimatic reconstruction}

The mean annual temperature (MAT) at the sites under study varies around the $10.6{ }^{\circ} \mathrm{C}$ level recorded at Valdavara-1 
and El Mirón, the sites located furthest north; the lowest mean temperature $\left(9.7^{\circ} \mathrm{C}\right)$ was recorded at El Portalón in Burgos, and the highest $\left(12.4^{\circ} \mathrm{C}\right)$ at La Sala de las Chimeneas, situated in the city of Cáceres, the southernmost site (Table 2).

The mean temperatures of the warmest months show narrow margin changes among the various sites in spite of the considerable geographical distance separating them. The temperatures range from $17.3{ }^{\circ} \mathrm{C}$ at El Mirón to $19.3{ }^{\circ} \mathrm{C}$ at El Portalón. For the coldest months, by contrast, there are greater differences between the northern and the southern sites. Noteworthy among the northern sites are the $2.2^{\circ} \mathrm{C}$ calculated at Valdavara and the $2.5^{\circ} \mathrm{C}$ at El Portalón, whereas at El Mirón our calculations yielded a temperature of $3.2^{\circ} \mathrm{C}$ and at La Sala de las Chimeneas, which is located in the southwestern part of the Iberian Peninsula, the temperature was calculated at $6.6^{\circ} \mathrm{C}$ (Table 2).

The calculated mean annual precipitation (MAP) for the sites is highest at La Sala de las Chimeneas with a total of $1193 \pm 461 \mathrm{~mm}$, whereas the lowest total is $806.7 \pm 354.6$ mm, at the El Portalón site (Table 2).

\section{Discussion}

The LGM was marked by abrupt and regular climatic changes, which a great variety of scientific analyses have attempted to define some references here (Fig. 3). The marine core analyses collected at different points off the coast of the Iberian Peninsula helped to define the ecosystems of the territory, but it was specifically the palynological study of the cores carried out in the Alboran Sea (MD95-2043), as well as the analysis from Padul (Sierra Nevada), that demonstrated the rapid development of the woodland accompanied by the expansion of semi-desert vegetation during the interstadials as the response of the vegetation to the rapid climate changes of the LGM (Sánchez-Goñi and D'Errico, 2005; Fletcher and Sánchez-Goñi, 2008; Fletcher et al., 2010). These characteristics were described using palynological data and have been corroborated by the present study of small mammals (Fig. 3 ). This study has suggested a predominance of woodland at all the sites (Fig. 2), due to the abundant presence of species whose environmental requirements tie them to this type of habitat, as is the case with Apodemus sylvaticus, Microtus arvalis and Eliomys quercinus (Fig. 2).

Moreover, the study of pollen fluctuations (Kageyama et al., 2005) established that the climate was cold and wet during the LGM, while analysis of the lakes has shown a higher degree of humidity than in other areas of Europe during the same period (Peyron et al., 1998). In the samples analysed, we have identified a great number of species indicating an environment with a high level of humidity, such as Arvicola terrestris, Microtus agrestis, Talpa europaea, Talpa occidentalis and Erinaceus europaeus. Furthermore, these species are abundant at all the sites studied (Table 1).

Proof that the Iberian Peninsula enjoyed a gentler climate than the rest of Europe is that it served as a refugium for certain Euro-Siberian species (Real et al., 2003; Sommer and Nadachowski, 2006; López-García et al., 2010b) that belonged to chorotype 1. Examples include Chionomys nivalis,

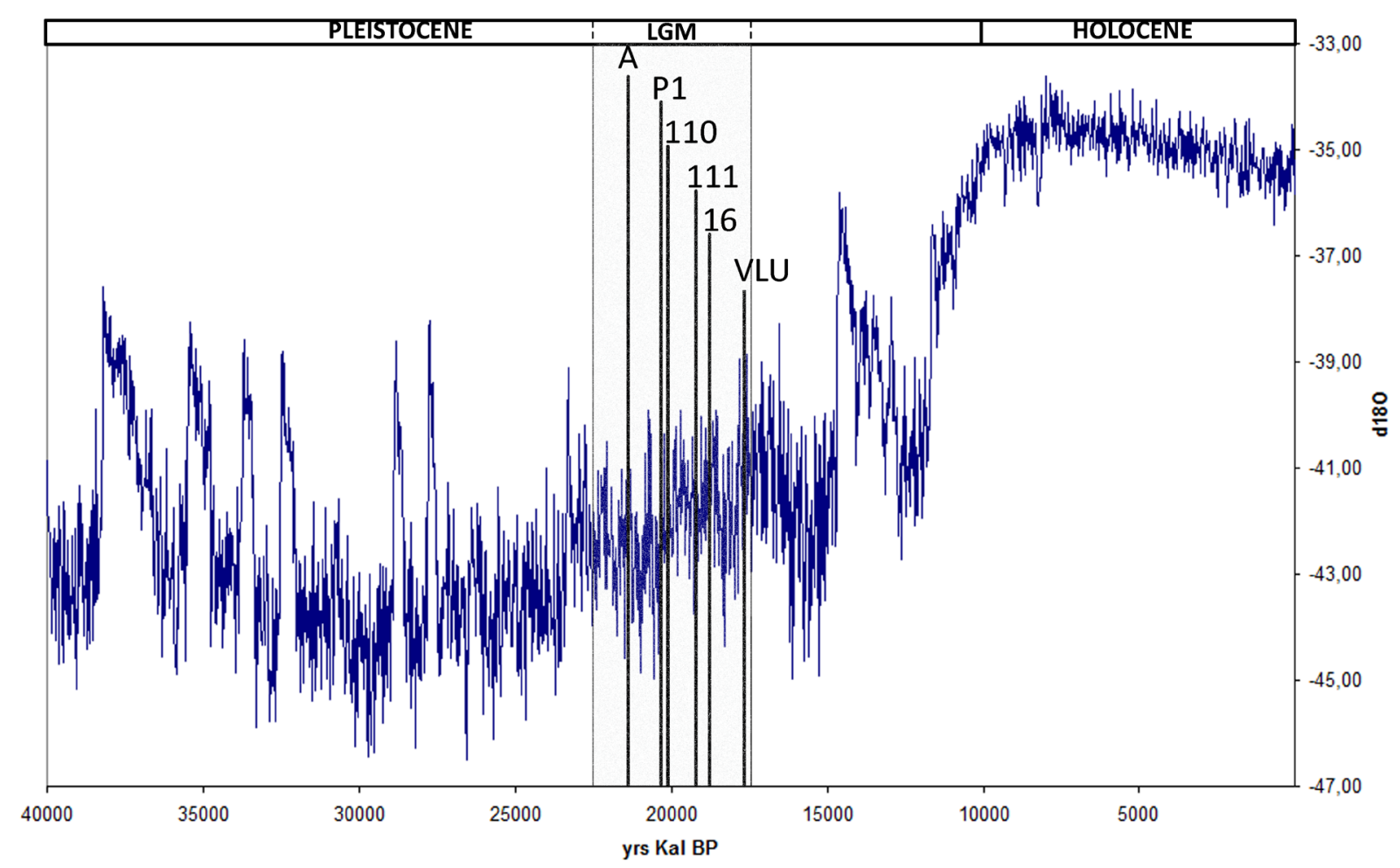

Fig. 3.- Relation between the Greenland isotope curve and the dating of each of the levels under study. 

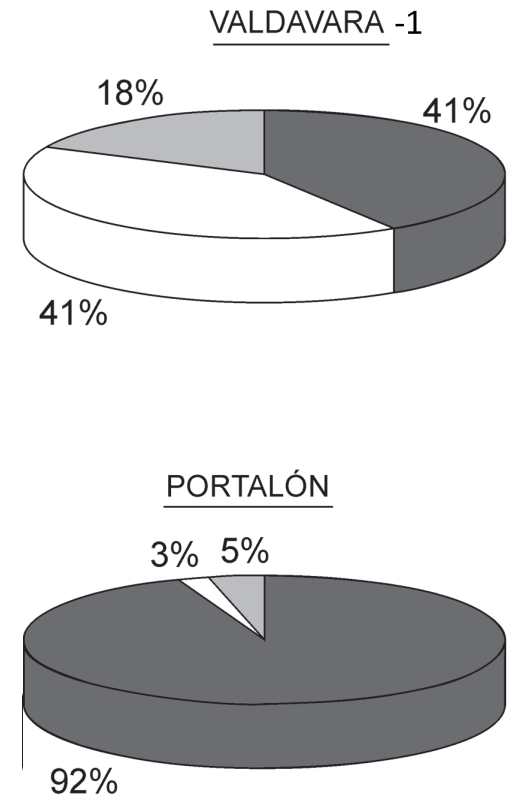

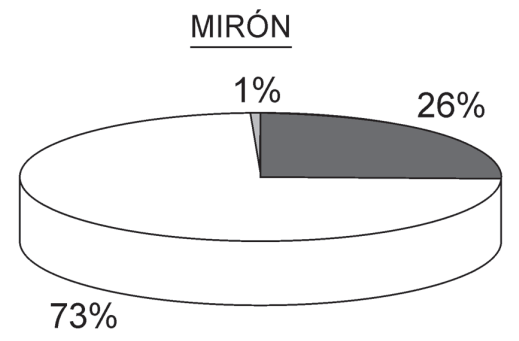

CUEVA DE MALTRAVIESO SALA DE LAS CHIMENEAS

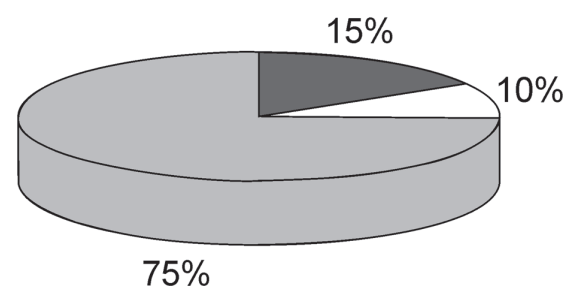

Fig. 4.- Percentage of chorotypes at each of the sites under study.

Chorotype 1

Chorotype 2

Chorotype 3

Microtus oeconomus, Microtus agrestis and Microtus arvalis (Table 1), found at all the sites studied. Moreover, at most of the sites, these cold regions taxa of cold regions coexist with thermo-Mediterranean species belonging to chorotype 3, species such as Microtus (Iberomys) cabrerae, Crocidura russula and Microtus (Terricola) duodecimcostatus, which represent a smaller percentage of the total (Table 1).

Nonetheless, this pattern of coexistence between two types of taxa with such diverse climatic requirements is not similar at all the sites. We therefore drew a comparison with the palaeoclimatic data derived from the MCR study, enabling us to establish a number of regional nuances. The site of El Portalón shown the most clear presence of Euro-Siberian or "chorotype 1" species, to the point of making up 92\% (Figure 4) of the analysed sample; this site also has the lowest mean annual temperature (MAT) of all the sites $\left(9.7 \pm 1.7^{\circ} \mathrm{C}\right)(\mathrm{Ta}-$ ble 2). Even so, it should be remarked that $3 \%$ of this group comprises Neomys anomalus (Table 1), which forms part of chorotype 2 ; in other words, in spite of characteristically inhabiting areas with low temperatures, they are reasonably tolerant of Mediterranean climatic conditions (Sans-Fuentes and Ventura, 2000). Another point to stand out is the presence of a number of remains of $M$. (Iberomys) cabrerae, the thermo-Mediterranean species par excellence, which belongs to chorotype 3 . This is attributable to the high temperatures $\left(19.3 \pm 1.0^{\circ} \mathrm{C}\right)$ (Table 2) recorded in the area in the warmest months.

At Valdavara-1, the presence of Euro-Siberian species (chorotype 1) represents $41 \%$ of the total of the sample (Figure 4), with the percentage of Chionomys nivalis or European snow vole being the highest $(20.8 \%)$ of the studied sites (Table 1). One reason for this fact is that the mean temperature of the coldest month was lower than elsewhere $\left(2.2 \pm 2.3^{\circ} \mathrm{C}\right)$ (Table 2). In spite of this, we also find M. (Iberomys) cabrerae represented, albeit at a low percentage $(2.1 \%)$ (Table 1$)$; this is a species that belongs to chorotype 3 and has highly specific Mediterranean climatic requirements. In addition, there are other species such as M. agrestis and Sorex minutus (chorotype 3), albeit with a low numerical representation (Table 1), which despite preferring to live at low temperatures are able to tolerate Mediterranean climatic conditions (SansFuentes and Ventura, 2000; Real et al., 2003; López-García et $a l ., 2010 b)$. This fact can perhaps be explained by considering that the region where the site is located lies at the boundary between the Oceanic and the Mediterranean climate.

The Euro-Siberian species represented at El Mirón, represent only $26 \%$ of the total (Fig. 4). Particularly noteworthy the presence of is Chionomys nivalis at 7.2\%, and above all the presence of two species that are currently extinct on the Iberian Peninsula, Pliomys lenki and Microtus oeconomus (Table 1). The presence of Pliomys lenki is very significant, for El Mirón (level 16) is one of the places for the last appearances in Europe; the species went completely extinct with the MIS2, at the end of the LGM, possibly due to competition with other species with a similar ecology (Cuenca-Bescós et al., 2008; 2009; 2010). Microtus oeconomus is currently extinct on the Cantabrian coast, having retreated to northern Europe (Cuenca-Bescós et al., 2008; 2009). Another important point concerning this site is that - even though no remains of M. (Iberomys) cabrerae (chorotype 3) or any other thermo- 


\begin{tabular}{|c|c|c|c|c|c|c|c|c|c|c|c|c|c|c|c|c|c|c|}
\hline & & & & & & & & & & & \multirow{2}{*}{\multicolumn{4}{|c|}{ MTC $\left({ }^{\circ} \mathrm{C}\right)$}} & \multirow{2}{*}{\multicolumn{4}{|c|}{ MAP $(\mathrm{mm})$}} \\
\hline & \multicolumn{4}{|c|}{ MAT $\left({ }^{\circ} \mathrm{C}\right)$} & \multicolumn{4}{|c|}{ MTW $\left({ }^{\circ} \mathrm{C}\right)$} & & & & & & & & \\
\hline SITE & LEVEL & DATING & Mean \& SD & Max & Mn & $\triangle$ & Mean \pm SD & Max & Mln & $\triangle$ & Mean \pm SD & Max & Mln & $\triangle$ & Mean \pm SD & Max & Min & $\triangle$ \\
\hline $\mathrm{CH}$ & 1 & $21630 \pm 21270$ & $12.4 \pm 1.1$ & 15 & 9 & -3.7 & $18.8 \pm 1.6$ & 23 & 15 & -1.1 & $6.6 \pm 2.2$ & 9 & 2 & -7.2 & $1193 \pm 416$ & 2000 & 500 & 712 \\
\hline $\mathrm{Ml}$ & $\begin{array}{l}110 \\
111 \\
16\end{array}$ & $\begin{array}{l}20020 \pm 18660 \\
20190 \pm 19070 \\
18750 \pm 17830\end{array}$ & $10.6 \pm 0.7$ & 11 & 9 & -3.6 & $17.3 \pm 0.3$ & 18 & 16 & -2.3 & $3.2 \pm 0.7$ & 4 & 3 & -3.5 & $1025 \pm 292.3$ & 1500 & 700 & -244 \\
\hline VLD & VLU & $17890 \pm 17730$ & $10.6 \pm 1.8$ & 14.5 & 8 & -0.5 & $18.5 \pm 1.6$ & 22 & 16 & 1.4 & $2.2 \pm 2.3$ & 6 & -1.0 & -3.7 & $1123 \pm 235$ & 1500 & 500 & 90 \\
\hline$P$ & P1 & $20500 \pm 20140$ & $9.7 \pm 1.7$ & 12 & 5 & -0.2 & $19.3 \pm 1.0$ & 20.5 & 18.5 & 0.8 & $2.5 \pm 0.5$ & 3 & 2.0 & -0.1 & $806.7 \pm 354.6$ & 2500 & 400 & 234.7 \\
\hline
\end{tabular}

Table 2.- Relation of the temperature and precipitation levels obtained by the MCR (Mutual Climate Range) analysis of the small mammals at each of the sites studied: MAT (mean annual temperature); MTW (mean temperature of the warmest months); MTC (mean temperature of the coldest months) and MAP (mean annual precipitation). Mean \pm SD (mean and standard deviation of the values obtained): Max (maximum of the values obtained); Min (minimum of the values obtained); $\Delta$ (difference between the current means at the meteorological stations of Cáceres, Santander, Lugo and Burgos, respectively, as measured over the last 30 years, and those obtained on the basis of the small-mammal study). The abbreviations are as follows: CH: La Sala de las Chimeneas; MI: El Mirón; VLD: Valdavara-1 and P: El Portalón.

Mediterranean species sensu stricto have been identified, analysis of the temperatures has revealed it was the site with the gentlest temperatures. It has the lowest mean temperature of the warmest month of the analysed set of sites $(17.3 \pm 0.3$ ${ }^{\circ} \mathrm{C}$ ), and the highest mean temperature of the coldest month among the northernmost sites $\left(3.2 \pm 0.7^{\circ} \mathrm{C}\right)$ (Table 2). This low variability is possibly due to its proximity to the sea, although the cave is currently located some $25 \mathrm{~km}$ from the coastline and it is known that during the LGM it would have been between 5 and $10 \mathrm{~km}$ further away (Cuenca-Bescós et al., 2009).

Finally, a mere $8 \%$ of the faunal assemblage of La Sala de las Chimeneas consists of Euro-Siberian species, as opposed to $17 \%$ (Fig. 4) for thermo-Mediterranean species (Table 1). Moreover, this is the only site at which there is no presence of $C$. nivalis (chorotype 1), and it is the site that presents the greatest percentage $(9.6 \%)$ of $M$. (Iberomys) cabrerae (chorotype 3 ), that marks a clear difference with respect to the sites located further north. These data are further corroborated by the temperature analysis, which reveals that the site had a higher mean temperature of the coldest month $\left(6.6 \pm 2.2^{\circ} \mathrm{C}\right)$ (Table 2) than the rest of the sites analysed.

Furthermore, we should emphasize that the chronologies of the sites studied seem to belong to the end of the Last Glacial Maximum. Some authors suggest that during this period an incipient decline in the ice sheets of the Northern Hemisphere occurs at $17.5 \mathrm{ka}$ (Svensson et al., 2006; Clark et al., 2009). This event could explain the presence of Euro-Siberian species such as $C$. nivalis and thermo-Mediterranean species such as M. (I.) cabrerae in the Iberian Peninsula.

Comparison of the current temperature and precipitation data at the studied sites with the data inferred from the MCR analysis has revealed that the temperatures were not particularly rigorous during the LGM (Table 2). This conclusion corroborates the pollen studies (Kageyama et al., 2005), which have established that the temperature and precipitation levels do not differ greatly from those at present.

Comparing the palaeoclimatic data with present-day data for the studied areas, it is evident that, even though they show a lower MAT during the LGM at the four sites studied, this is not a very marked decrease (Table 2). The lower level is observed specially in the mean temperature data of the coldest months; particularly noteworthy is the lesser difference for El Portalón $\left(-0.1{ }^{\circ} \mathrm{C}\right)$, which indicates that basically the same temperature is maintained at present, and the extreme difference of $-7.2^{\circ} \mathrm{C}$ at La Sala de las Chimeneas (Table 2). Comparing the LGM and present data, the harsher temperatures occurred to a greater extent in the southern half of the Iberian Peninsula, whereas Valdavara-1 and El Mirón show differences of $-3.7^{\circ} \mathrm{C}$ and $-3.5{ }^{\circ} \mathrm{C}$ respectively (Table 2). By contrast, the mean temperatures of the warmest months do not display great changes (Table 2), although it should be pointed out that minor increases occur during the LGM in the mean temperatures at Valdavara-1 and El Portalón, of $1.4^{\circ} \mathrm{C}$ and $0.8^{\circ} \mathrm{C}$ (Table 2), respectively. Finally, precipitation levels do show some notable features. It can be observed that the greatest difference among our data occurs at La Sala de las Chimeneas, with a difference of $712 \mathrm{~mm}$ (Table 2). This large variation in precipitation with respect to present day data was also observed in studies carried out in areas adjacent to $\mathrm{La}$ Sala de las Chimeneas. This is the case with an anthracological study carried out in the Portuguese Extremadura, which confirms a much higher precipitation in the southwestern part of the Iberian Peninsula during the LGM (Figueiral and Terral, 2002). At El Mirón, by contrast, our calculations show the only rise in precipitation with respect to the LGM, for which a difference of $-244 \mathrm{~mm}$ has been calculated (Table 2).

\section{Conclusions}

On a global scale, during the LGM, temperature and precipitation levels reached minimal values. However, our study shows a more detailed picture. Although the temperatures were lower than today in Iberia during the LGM, the harsher climatic conditions evident in the rest of Europe are not detected. Moreover, our study covers the end of the LGM, which was characterized by the incipient retreat of the icesheets in the Northern Hemisphere.

Certain Euro-Siberian species found a refuge here from the harsh climatological conditions that prevailed in the rest of Europe, as well as Microtus oeconomus, which is currently 
only found in the north of Europe. Moreover, we have also seen how these species coexisted with thermo-Mediterranean taxa such as M. (Iberomys) cabrerae and Microtus (Terricola) duodecimcostatus. Analysing the distribution of $M$. (Iberomys) cabrerae, it is evident that its presence increases away from the Cantabrian coast, because this is a species that inhabits a Mediterranean climate with mild temperatures. A similar phenomenon occurs with Microtus (Terricola) duodecimcostatus, which is replaced at more northern latitudes by Microtus (Terricola) lusitanicus, a more tolerant species of the low temperatures. In the case of the European snow vole Chionomys nivalis, by contrast, we find it represented at all the sites except at La Sala de las Chimeneas.

However, the palaeoclimatic data do not show major differences with today's conditions. The results of the MCR analysis reveal a similar decrease in the mean annual temperatures at the four studied sites, though it is at La Sala de las Chimeneas that the greatest decrease is observed in the mean temperatures of the coldest months. With respect to the levels of precipitation, we see a notable increase in the most of studied sites, but once again this increase is much greater at La Sala de las Chimeneas. In short, the increase in precipitation, together with the cool temperatures, contributed to the great development of the woods and wet open areas throughout the Iberian Peninsula, from the north to the south, thus fostering a great diversity of species most of which still inhabit the Iberian Peninsula.

Finally, the palaeoenvironmental and palaeoclimatic results obtained with the analysed small-mammal remains coincide with the previously published palynological, anthracological and palaeoherpetological studies.

\section{Acknowledgments}

This article was supported by the projects PO BOS 20038938, DGI CGL 2006 13532-C03-01-02, 2002-02-4.1-U-048, CGL2009-07896/BTE, SGR2009-324. J.M.L-G benefited a Beatriu de Pinós Postdoctoral fellowship (2011BP-A00272) from the Generalitat de Catalunya, a grant co-funded by the European Union through the Marie Curie Actions of the 7th Framework Program for R\&D. I. L-F benefited pre-doctoral subsidy from the Fundación Atapuerca. And we are also grateful to the reviewers, Dr. Adam Nadachowski and Dr. Alexey. S. Tesakov, for their comments, that strongly improved the manuscript.

\section{References}

Agustí, J., Blain, H.A., Cuenca-Bescós, G., Bailon, S. (2009): Climate forcing of first hominid dispersal in western Europe. Journal of Human Evolution 57, 815-821. http://dx.doi.org/10.1016/j. jhevol.2009.06.005.

Andrews, P. (1990): Owls, Caves and Fossils. Oxford University Press. London. 231p.

Andrews, P. (2006): Taphonomic effects of faunal impoverishment and faunal mixing. Palaeogeography, Palaeoclimatology, Palaeoecology 241, 572-589.

Bañuls, S., López-García, J.M., Blain, H.-A., Canals, A. (2012): Climate and landscape during the Last Glacial Maximum in southwestern Iberia: the small vertebrate association from the Sala de las Chimeneas, Maltravieso, Extremadura. Comptes Rendus Palevol 11, 31-40. http:// dx.doi.org/10.1016/j.crpv.2011.10.001.

Blain, H.-A. (2005): Contribution de la paléoherpétofaune (Amphibia \& Squmata) a la connaissance de l'évolution du climat et du paysage du Pliocene supérieur au Pléistocene moyen d'Espagne. Paris, Museum National d'Histoire Naturelle. Tesis Doctoral: 402 p.

Blain, H.-A., Bailon, S., Agustí, J. (2007): Anurans and squamate reptiles from the latest early Pleistocene of Almenara-Casablanca-3 (Castellón, East of Spain). Systematic climatic and environmental considerations. Geodiversitas 29(2), 269-295.

Blain, H.-A., Bailon, S., Cuenca-Bescós, G. (2008a): The Early-Middle Pleistocene palaeoenvironmental change based on the squamate reptile and amphibian proxy at the Gran Dolina site, Atapuerca, Spain. Palaeogeography, Palaeoclimatology, Palaeoecology 261, 177-192. doi: 10.1016/j.palaeo.2008.01.015.

Blain, H.-A., Bailon, S., Cuenca-Bescós, G., Arsuaga, J.L., Bermúdez de Castro, J.M., Carbonell, E. (2009): Long-term climate record inferred from Early-Middle Pleistocene amphibian and squamate reptile assemblages at the Gran Dolina Cave, Atapuerca, Spain. Journal of Human Evolution 56(1), 55-75. doi: 10.1016/j.jhevol.2010.04.002.

Blain, H.-A. (2009): Contribution de la paléoherpétofaune (Amphibia \& Squamata) à la connaissance de l'évolution du climat et du paysage du Pliocène supérieur au Pléistocène moyen d'Espagne. Treballs del Museu de Geología. Barcelona 16, 39-170.

Blain, H.-A., Bailon, S., Cuenca-Bescós, G., Bennàsar, M., Rofes, J., López-García, J.M., Huguet, R., Arsuaga, J.L., Bermúdez de Castro, J.M., Carbonell, E. (2010): Climate and environment of the earliest West European hominins inferred from amphibian and squamate reptile assemblages: Sima del Elefante Lower Red Unit, Atapuerca, Spain. Quaternary Science Reviews 29, 3034-3044. doi: 10.1016/j. quascirev.2010.07.006.

Canals, A., Rodríguez-Hidalgo, A., Peña, L., Mancha, E., García-Díez, M., Bañuls, S., Euba, I., López-García, J. L., Barrero, N., Bermejo, L., García, F. J., Mejías, D., Modesto, M., Morcillo, A., Aranda, V., Carbonell, E. (2010): Nuevas aportaciones al Paleolítico superior del suroeste peninsular: "La cueva de Maltravieso, más allá del santuario extremeño de las manos". In: Jornadas internacionales sobre el Paleolítico superior peninsular. Novedades del S.XXI. Homenaje al profesor Javier Fortea. SERP Seminaris d'estudis i recerques prehistòriques-UB: 199-218.

Clark, P.U., Dyke, A.S., Shakun, J.D., Carlson, A.C., Clark, J., Wohlfarth, B., Mitrovica, J.X., Hostetlerand, S.W., McCabe, A.M. (2009): The Last Glacial Maximum. Science 325, 710-714. doi: $10.1126 /$ science. 1172873

Cuenca-Bescós, G., Strauss, L.G., González Morales, M.R., García Pimienta, J.C. (2008): Paleoclima y paisaje del final del cuaternario en Cantabria: los pequeños mamíferos de la cueva del Mirón (Ramales de la Victoria). Revista Española de Paleontología 23 (1), 91-126.

Cuenca-Bescós, G., Straus, L.G., González Morales, M.R., García Pimienta, J.C., (2009): The reconstruction of past environments through small mammals: from the Mousterian to the Bronze Age in El Mirón Cave (Cantabria, Spain). Journal of Archaeological Science 36 (4), 947-955. doi: 10.1016/j.jas.2008.09.025.

Cuenca-Bescós, G., Strauss, L.G., García-Pimienta, J.C., González Morales, M., López-García, J.M. (2010): Late Quaternary small mammal turnover in the Cantabrian Region: The extinction of Pliomys lenki (Rodentia, Mammalia). Quaternary International 212, 129-136. doi: 10.1016/j.quaint.2009.06.006. 
Damms, R. (1981): The dental pattern of the dormice Dryomys, Myomimus, Microdyromys and Peridryomys. Micropaleontological Bulletins 3, 1-115.

Eastham, A. (1995): Chapitre 19. La Microfaune. In: L. G. Straus (Ed.): Les derniers chasseurs de rennes du Monde Pyrénéen. L'Abri dufaure: un gisement tardiglaciaire en Gascogne. Mémoire Societé Préhistorique de France 22, 235-245.

Evans, E.M.N., Van Couvering, J.A.H., Andrews, P. (1981): Palaeoecology of Miocene sites in Western Kenya. Journal of Human Evolution 10, 99-116.

Figueiral, I., Terral, J-F. (2002): Late Quaternary refugia of Mediterranean taxa in the Portuguese Estremadura: charcoal based palaeovegetation and climatic reconstruction. Quaternary Science Reviews 21, 549-558.

Fletcher, W.J., Sánchez Goñi, M.F. (2008): Orbital and sub-orbitalscale climate impacts on vegetation of the western Mediterranean basin over the last 48.000 yr. Quaternary Research, 70. 451-464. doi: 10.1016/j.yqres.2008.07.002.

Fletcher, W.J., Sánchez Goñi, M.F., Allen, J.R.D., Cheddadi, R., Combourieu Nebout, N., Huntley, B., Lawson, I., Londeix, L., Magri, D., Margari, V., Müller, U.C., Naughton, F., Novenko, E., Roucoux, K., Tzedakis, P.C. (2010): Millennial-scale variability during the last glacial in vegetation records from Europe. Quaternary Science Reviews 29, 2839-2864. doi: 10.1016/j.quascirev.2009.11.015.

Font Tullot, I. (2000): Climatología de España y Portugal. Salamanca, Universidad de Salamanca: 422 p.

Kageyama, M., Combourieu Nebout, N., Sepulchre, P., Peyron, O., Krinner, G., Ramstein, G., Cazet, J.-P. (2005): The Last Glacial Maximum and Heinrich Event 1 in terms of climate and vegetation around the Alborán Sea: a preliminary model-data comparison. Comptes Rendus Geosciences 337, 983-992. doi: 10.1016/j.crte.2005.04.012.

López-García, J.M., Blain, H. A., Cuenca-Bescós, G., Ruiz-Zapata, M.F., Dorado-Valiño, M. Gil-García, M.J., Valdeolmillos, A., Ortega, A. I., Carretero, J. M., Arsuaga, J.L., Bermúdez de Castro, J.M., Carbonell, E. (2010a): Palaeoenvironmental and palaeoclimatic reconstruction of the Latest Pleistocene of El Portalón Site, Sierra de Atapuerca, northwestern Spain. Palaeogeography, Palaeoclimatology, Palaeoecology 292, 453-464. doi: 10.1016/j.palaeo.2010.04.006.

López-García, J. M., Blain, H.-A., Allué, E., Bañuls, S., Bargalló, A., Martín, P., Morales, J. I., Pedro, M., Rodriguez, A., Solé, A., Oms, F. X. (2010b): First fossil evidence of an 'interglacial refugium' in the Pyrenean region. Naturwissenschaften 97, 753-761. doi: 10.1007/ s00114-010-0695-6.

López-García, J.M., Blain, H-A., Cuenca- Bescós, G., Alonso, C., Alonso, S., Vaquero, M. (2011): Small vertebrates (Amphibia, Squamata, Mammalia) from the late Pleistocene-Holocene of the Valdavara-1 cave (Galicia, northwestern Spain). Geobios 44, 253-269. doi: 10.1016/j.geobios.2010.10.00.
Meulen, van der A. J. (1973): Middle Pleistocene small mammals from the Monte Peglia (Orvieto, Italy) with special reference to the phylogeny of Microtus (Arvicolidae, Rodentia). Quaternarie 16, 1-144.

Pasquier, L. (1974): Dynamique évolutive d'un sous-genre de Muridae, (Apodemus sylvaticus). Etude biométrique des caractères dentaires de populations fossiles et actuelles d'Europe occidentale. Montpellier, Université de Montpellier: $184 \mathrm{p}$.

Palombo, J. L., Gisbert, J. (2005): Atlas de los Mamíferos Terrestres de España. Madrid, Dirección General para la Biodiversidad-SECEMSECEMU: 564 p.

Peyron, O., Guiot, J., Cheddadi, R., Tarasov, P., Reille, M., de Beaulieu, J.-L., Bottema, S., Andrieu, V. (1998): Climatic Reconstruction in Europe for 18,000 YR B.P. from Pollen Data. Quaternary Research 49, 183-196.

Pokines, J. (1998): The Lower Magdalenian Cantabrian Spain. BAR International Series, Oxford: $713 \mathrm{p}$.

Real, R., Guerrero, A.L., Márquez, J., Olivero, J., Vargas, J.M. (2003): Tipificación corológica de los micromamíferos ibéricos en relación con Europa y África. Graellsia 59(2-3), 287-298.

Reumer, J.W.F. (1984): Ruscinian and early Pleistocene Soricidae (Insectívora, Mammalia) from Tegelen (The Netherlands) and Hungary. Scripta Geologica 73, 1-173.

Sánchez - Goñi, M.F.,d'Errico, F. (2005): La historia de la vegetación y el clima del último ciclo climático (OIS5-OIS1, 140.000-10.000 años BP) en la Península Ibérica y su posible impacto sobre los grupos paleolíticos. Monografías del Museo de Altamira 20, 115-129.

Sans-Fuentes, M.A.,Ventura, J. (2000): Distribution patterns of the small mammals (Insectivora and Rodentia) in a trasnsitional zone between the Eurosiberian and the Mediterranean regions. Journal of Biogeography 27, 755-764.

Sevilla, P. (1986): Identificación de los principales quirópteros ibéricos a partir de sus dientes aislados. Valor sistemático de los caracteres morfológicos y métricos dentarios. Doñana Acta Vertebrata 13, 111-130.

Sommer, R.S., Nadachowski, A. (2006): Glacial refugia of mammals in Europe: evidence from fossil records. Mammal reviews 36(4), 251265.

Svensson, A.D., Andersen, K.K., Bigler, M., Clausen, H.B., DahlJensen, D., Davies, S.M., Johnsen, S. J., Muscheler, R., Rasmussen, S.O., Röthlisberger, R., Steffensen, J. P., Vinther, B.M., (2006): The Greenland Ice Core Chronology 2005, 15-42 ka. Part 2: comparison to other records. Quaternary Science Reviews 25, 3258-3267. doi: 10.1016/j.quascirev.2006.08.003

Vaquero, M., Alonso, S., Alonso, C., Ameijenda, A., Blain, H.-A., Fabregas Valcarce, R., Gómez, G., de Lombera, A., López-García, J.M., Lorenzo, C., Lozano, M., Rodríguez, C., Rosell, J., Serna, M.R. (2009): Nuevas fechas radiométricas para la Prehistoria del noroeste de la Península Ibérica: la cueva de Valdavara (Becerreá, Lugo). Trabajos de Prehistoria 66, 99-113. doi: 10.3989/tp.2009.09014. 